\title{
The Rights of Compensation to Community for Land Used for Mining Business According to Law Number 2 Year 2012 Regarding Land Procurement for Development and Public Interests
}

\author{
Ritawati \\ Faculty of Law \\ Jakarta Islamic University \\ Jakarta, Indonesia \\ ritawatiss@yahoo.co.id
}

\author{
Otom Mustomi \\ Faculty of Law \\ Jakarta Islamic University \\ Jakarta, Indonesia \\ otommustomi@g.mail.com
}

\author{
Fatimah \\ Faculty of Law \\ Jakarta Islamic University \\ Jakarta, Indonesia \\ fatimah@UID.ac.id
}

\begin{abstract}
With the enactment of Law No. 2 year 2012 on Land Procurement for Public Interest and Development, it raises the issue of agrarian conflict specifically for mineral and coal mining areas. It makes the right of the people in a weak position, where the community must move out of their land area of ownership under the pretext of compensation without the appropriate pattern of mining business permits. The absence of provisions on the regulation of the amount of compensation, and they are not involved at all in the decision making of the mining business. The granting of compensation rights and the ease of using the mining area will lead to prolonged agrarian conflicts, especially on land tenure issues, mining business, spatial problems resulting in environmental damage. The purpose of this research was to find out solutions to mining problems by prioritizing people's rights to land without causing public losses and harming mining business. In addition, to find out a legal solution by conducting an analysis to the government policy against the applicable legislation, without causing harm to the community and the occurrence of overlapping regulations. The research method used in this research was normative law research. The library materials were as basic data which in legal research science, the data were classified as secondary data. Thus facing agrarian conflicts that can never be resolved to date, the need for a Government Policy committed strongly to overcome the main problem, namely by not neglecting the rights of the community in obtaining compensation in accordance with the objectives of Article 33 of the 1945 Constitution and Article 3 of Law No. 2 of 2012 that the procurement of Land for Public Interest aims to provide land for the implementation of development in order to improve the welfare and prosperity of the nation, state and society while maintaining the legal interests of the Eligible Party.
\end{abstract}

Keywords - mining, legal consequences, law

\section{INTRODUCTION}

\section{A. Background}

The most current Agrarian Conflict is a mining problem related to the rights of the community and reaches the highest level of diversity in terms of its victims being forestry, plantation and mining. This will lead to a growing conflict with the enactment of Agrarian Law No. 2 of 2012 on Land Procurement for Public Interest and Development.
The problem arise with the construction of infrastructure projects, it will use this Law when it comes to the people's demands on land being used as the project site to obtain replacement of the land on which the development site is based. The issue of agrarian conflict in mineral and coal mining area is related to the existence of Law No. 2 year 2012, making the society in a weak position. They have to move out of the land area of their ownership under the pretext of compensation without the proper pattern of mining business permit and not involved at all in decision making of mining business. This can be seen in the coastal areas of South Java coast, East Kalimantan, South Kalimantan, West Nusa Tenggara, East Nusa Tenggara, Southeast Sulawesi, Central Sulawesi, Maluku Islands and Papua.

Data from the Agrarian Commission states that at least 64.2 million hectares of land or $33.7 \%$ of the land in Indonesia have been granted to mining and coal companies in the form of concession licenses. Moreover, data from the Mining Network, this data does not include the extent of oil and gas mining concessions. The total area of materials for mining business permit (IUP) reaches $41,750,107$ hectares. The Contract of Work (KK) totals 22,764,619.07 hectares and agreements by the coal mining company (PKP2B) covering an area of 7,088,078 hectares.[1]

Agrarian conflict can never be solved until now because the Government does not solve the main problem that is by not neglecting the rights of society in obtaining compensation in accordance with the objective of Article 33 paragraph (3) of the 1945 Constitution.

Coal mining, supposed to be inherent with spatial planning in policy-making and the determination of mining areas. Coal mining, which takes into account spatial planning, and synergies with provincial/district/city spatial planning, will minimize environmental impacts/environmental damage and pay attention to community rights to obtain compensation for land affected by mining areas.

Law No. 4 of 2009 on Mineral and Coal Mining or the Minerba Act and Law Number 26 Year 2007 on Spatial Planning and Law No. 2 of 2012 on Land Procurement for the Public Interest and Development, in fact lex specialis of 
Law Number 5 year 1960 on Basic Agrarian Stipulations (UUPA). As a parent law, the UUPA seems to lose the spirit of the relationship between mining and spatial planning and community rights as if it is not related. Understanding the essence of mining and spatial planning in UUPA construction, will be able to arrange and understand the rules and policies of mining.

The right to control the State Article 33 Paragraph (3) of the 1945 Constitution and Article 1 Paragraph (2) and Article 2 Paragraph (1) of the UUPA shall place the right to control the state as the basis and the origin of the rights of the agribusiness. Hence, the state power is then issued power in a smaller size, which in form, content, and the nature diverse. The individualistic function of state power means the function of making the individual members of the community into a possible state of affluence.

BAL (Basic of Agrarian Law) is as the basis of state control over the land, water and space, including natural resources contained in it including coal mining. Mining management is not separated from the land, in the implementation of the attachment principle, the landowner in the state exercises his right to the underground space in the form of a coal mining mineral deposit. In this case, it is limited to mineral objects that are solid (hard mineral).

\section{B. Problem Formulation.}

Based on the above background, it can be formulated problems as follows:

1. How to arrange the Mining in Agrarian Law and Mining Regulation?

2. How to Protect People's Right with Mining Business related to Law No. 2 year 2012 about Procurement of Land For Development?

\section{DISCUSSION}

\section{A. Arrangement on Mining in Agrarian Law and Mining Regulations}

To be able to do mining business, it is definitely needed a piece of land because mining activities are nothing but excavation. The existence of mine is mostly located in the bowels of the earth. A mining company to be able to run the mining activities must have a permit from the government. With the permission it has, the mining company cannot directly conduct mining according to the location designated in the permit concerned, but it is necessary to see first at the mining location, whether in the location there are rights on land owned by other parties. If there are rights to land it is not possible mining activities can be done just like that, given the government compared with mining rights.

\section{1) The Principles of Agrarian Law}

A plot of land is part of the earth that is located in the field of agrarian law. The law of agrarian scope is very broad because the arranged object is about earth, water, and space. Earth, water and space, derived from the gift of God Almighty as a national wealth that has a very important function is to build prosperity of Indonesian society.

Accordingly, in Article 33 Paragraph (3) of the 1945 Constitution stated that the earth, water and natural resources in it are controlled by the state and used to the greatest possible for the welfare of the people. This provision is the constitutional basis for the state's control over agrarian. It is said that his tenure is in the state, because in terms of his position the state is the organization of all the people of Indonesia. The purpose of the right to control by the state is for the greatest benefit for the welfare of the people. Furthermore, to achieve these objectives, it is necessary to prohibit that if the people have had good intentions to inhabit the land from the outset by utilizing it productively it is necessary to be protected and respected. And if the public interest requires this land, its rights may be revoked, guaranteed by the compensation of the land with do not degrade their quality of life.

\section{2) Right to Mining}

Mining issues also cannot be separated from agrarian problems, because as ever discussed, mining activities are in the earth (land) and to carry out such activities must obtain prior permission from the authorized officials.

As for mining rights, once a businessman obtains an environmental permit, a new mining permit is granted in the form of IUP (Mining Permit), IPR (Mining Permit for the People), and IUPK (Special Mining Business License) which is the right to mining.

\section{B. Protection of People's Rights with the existence of Mining Business related to Law No. 2 of 2012 on the Procurement of Land for Development}

The law of mining has a very close relationship with the agrarian law. This is closely related to the utilization of land for mining purposes. For individuals and legal entities that will conduct mining in mining areas. What must be known earlier is about the legal status of land to be used. The land status is ownership rights, tenure, use rights, use rights, and or state land.

If the land to be used is a property right, the mining company must provide reasonable compensation to the landowner. Compensation is not only to the land concerned, but also to the objects that exist on it, such as plants, buildings and others. Likewise, if the land used is a state land, the company/individual must apply to the National Land Agency (BPN) in order to be granted the Right to Builds (HGB) and the Right to Use (HGU). The application for building rights is closely related to the utilization of land for the purpose of establishing office buildings at that location. Likewise, the granting of rights to use, namely the granting of the right to commercialize state land for mining business interests, which includes the exploitation and exploration business.

According to Adam Smith, what is called as justice really has only one meaning: commutative justice concerning equality, balance, harmony of relationships between one person or parties with other persons or parties. Legal justice is already contained in commutative justice, because legal justice is actually only more consequence. Furthermore, the principle of commutative justice must be neutral and treat all parties together without exception.[2]

Adam Smith rejected distributive justice as one type of justice as expressed by John Rawls[3]. The reasons are, justice always concerns on the rights of all persons not to be impaired or that everyone should be treated in accordance with their rights. 
There are three basic principles of commutative justice according to Adam Smith, namely:

\section{1) No Harm Principle}

According to Adam Smith the most fundamental principle of justice is the principle of no harm or principle does not harm others. The foundation of this principle is respect for human dignity and dignity and its inherent rights, including the right to life.

\section{2) Non-intervention principle}

The principle of non-intervention is the principle of noninterference. This principle requires that for the sake of guarantee and respect for the rights and interests of everyone is not allowed to interfere in the lives and activities of others.

\section{3) The principle of fair exchange}

The principle of fairness of exchange particularly manifested and revealed in the pricing mechanism in the market. This is in fact a further application of the principle of no harm specifically in exchange between one party and another in the market.

The legal basis of city arrangement refers to the legal basis of spatial arrangement, among others, provided for in Article 14 paragraph (1) of the BAL, which in the designation and use of earth, water and space as well as the natural resources contained therein, one of them is mining. The stewardship of this land is manifested in a spatial plan. Spatial arrangement is set in Law Number 26 Year 2007 on Spatial Planning. In spatial planning in accordance with the spatial plan will cause legal consequences in accordance with the right to land. Space as a natural resource knows no borders. But space is associated with the setting, then it must be clear the limits, functions and systems in one unit.

The land and spatial aspects of land have important connections, since land as one of the resources of population activity can be judged by its nature, process and its use. This is in accordance with what Firey proposed, "Land can show a great cultural influence in space adaptation, space can be a symbol of social values (eg, the population often gives great historical value to a plot of land). In Article 18 of the BAL, the right to land is the right and the obligation, the authorities and the benefit in using the land which in itself includes the physical land and its environment and the space above it.

Spatial and land use arrangements, in Article 16 of the $\mathrm{BAL}$, require the government to draft a general plan on the inventory, designation and use of land for various development purposes. In spatial planning related to mining management, referring to the general land use plan, based on the physical objective conditions of the land and the environment, both at the provincial and district/city levels shall have in common. Based on Law No. 2 of 2012 on Procurement for Public Interest and Development, this is in the implementation of the stipulation of development plans to the public interest, in accordance with and based on the pre-determined Spatial Plan (RTRW), including in the determination of mining management area.

The authority to master in the concept of the right to control the state is used to achieve the greatest prosperity of the people and its implementation can be authorized to regions and indigenous and tribal peoples. The state does not have, but acts as the holder of power. So it is public or governmental (berstuursdaat). The basic objectives of the concept controlled by the state in Article 33 Paragraph (3) of the 1945 Constitution as well as the UUPA are affirmed that the right to control by the state is the greatest prosperity of the people. Based on the purpose mentioned, there are some restrictions that should not be violated, namely:

a. If in good faith the lands have been occupied and utilized by the people, then the statement must be respected and protected. The existence of the people in these lands is one of the manifestations of the prosperity of the people. The people shall have the right to take precedence over the new occupants which apply the applicable legal formalities; and

b. State-controlled land, but has been exploited by the people with good bond (ter geode throuw) can only be revoked or exiled from them, solely for public interest, ie for the social interest and/or the interest of the state.

c. Any deprivation or termination of a legal relationship or concrete relationship occupied or utilized in good faith shall be guaranteed not to degrade their status or quality due to their relationship to the land. (Bagir Manan: 2005).

In explanatory memory II/8 UUPA, land for inventory, allotment, and its use must be through a plan. This planning can be interpreted, that the UUPA, in the use of mining area. There must be planning in the RTRW (Regional and Space Planning) of a province/district/city in a development process. The designation is in the framework of the spatial management of mining, which is related to the development of a region of a province/district/city in the development to be undertaken.

\section{CONCLUSIONS}

The right of state authority in accordance with Article 2 paragraph (2) in Law Number 5 Year 1960 to perform the act of controlling the right to land is to be in accordance with the Basic Agrarian Law (UUPA) which still pay attention to people's rights as a right recognized as a form of land rights which is regulated by law. And the right of this authority should not be separated from the greatest purpose for the people welfare. Meanwhile, people are not free to use the earth, water and natural wealth contained in it and space. For people in need are required to request permission to the state/government. In principle, the government will grant these permits as long as the requirements or procedures have been met.

Mining occurring on the land of recognized rights to exist in the UUPA must be resolved first, the mine must pay attention to the regulation in the mining law stating that the right to mining is not the right to land on it but the right to mining in the bowels of the earth. Thus, there must be an agreement between the owner of the land right thereon and those with mining rights in the area that have been granted permission from the Government to do mining.

\section{REFERENCES}

[1] "No Title." [Online]. Available: https://nasional.kompas.com

[2] "The Theory of Justice According to Some Experts." [Online]. Available: http:/hadasiti.blogspot.com/2012/11/teori-keadilanmenurut-para-ahli.html\#!/2012/11/teori-keadilan-menurut-paraahli.html. [Accessed: 26-Nov-2014].

[3] "Filsafat John Rawls tentang Teori Keadilan," Mukkadimah, vol. 19, no. 1, p. $51,2013$. 